\title{
Sequence stratigraphy of Upper Jurassic reservoir sandstones in the northern part of the Danish Central Trough, North Sea
}

\author{
Peter N. Johannessen, Karen Dybkjar and Erik S. Rasmussen \\ Geological Survey of Denmark and Greenland, GEUS, Thoravej 8, DK-2400, \\ Copenhagen NV, Denmark
}

\begin{abstract}
Received 19 May 1995; accepted in revised form 20 April 1996
The Jurassic succession of the northern part of the Danish Central Trough is subdivided into six depositional sequences based on a multi-disciplinary study, including sedimentology, biostratigraphy, seismic interpretation, structural interpretation, log correlation, geochemistry and palynofacies analysis. Three of these sequences include significant sandstone deposits that represent potential reservoirs. The lowermost sequence 1 contains Upper Kimmeridgian backbarrier and shoreface sandstones of the 'basal sandstone unit' and the Heno Formation deposited within a transgressive and a highstand systems tract, respectively. Sequence 2 includes Upper Kimmeridgian middle shoreface sandstones of the Heno Formation deposited within a transgressive systems tract. Within sequence 6, Middle-Upper Volgian distal turbidite sandstones have been recognized. These are interpreted as having been deposited within a lowstand and transgressive systems tract and may constitute a reservoir elsewhere in the basin. The sequence stratigraphic boundaries of this study do not match those proposed by the Exxon group. In this rift setting, sequence development was probably controlled predominately by tectonism; eustasy was of subordinate importance. Copyright (C) 1996 Elsevier Science Ltd
\end{abstract}

Keywords: Late Jurassic; sequence stratigraphy; North Sea

The purpose of this paper is to describe the facies and distribution of deeply buried Upper Jurassic reservoir sandstones deposited within a tectonically active rift basin, using the principles of sequence stratigraphy. We also present the sequential development of the sediments within a platform graben setting that experienced variable subsidence rates.

The study is focused on the Feda and Gertrud Grabens in the northern part of the Danish Central Trough, penetrated by the Gert-1, Gert-2, Jeppe-1 and Gwen-2 wells (Figure 1). The oil-bearing Gert Field, which is awaiting development, is situated within the study area. The net sand thickness of the Gert-1 well reservoir is $72 \mathrm{~m}$ with an average porosity of $16 \%$. The reserves are estimated to be 11 million $\mathrm{m}^{3}$ oil condensate and 1 billion $\mathrm{m}^{3}$ gas (Damtoft et al., 1992). The reservoir sandstones of the Gert field and adjacent areas are very deeply buried (base sandstone in the Gert-1 well occurs at $4938 \mathrm{~m}$ below M.S.L.) resulting in limited seismic resolution. The sequence stratigraphic interpretations presented here are thus based on the integration of seismic stratigraphy, with sedimentological and palynofacies interpretations based on cores, detailed well log correlations, biostratigraphy and geochemistry.

\section{Geological setting}

Regional geology

The Central Trough is situated within the North Sea, south of the Viking Graben and Moray Firth and runs through the British, Norwegian, Danish, German, and Dutch North Sea sectors (Figure I). It is a complex, rifted epicontinental basin with a long history of differential subsidence (Roberts et al., 1990). The Danish Central Trough has experienced overall extension and is characterized by a number of Jurassic half-grabens (Figure 2) (Damtoft et al., 1992). The fault blocks are tilted towards the NE. As a result of NW-SE strike-slip movements, local areas experienced compression, forming thrusted ridge structures (Damtoft et al., 1992).

The combined effects of graben and half-graben subsidence and Middle Jurassic (Bathonian) to Late Jurassic (early Volgian) eustatic sea-level rise (Hallam, 1988; Haq et al., 1988) resulted in a major transgression within the Central Trough. The northern part of the Danish Central Trough experienced marine inundation from the north at a time when the Søgne Basin and Feda Graben underwent major subsidence (Figure 1) (Damtoft et al., 1992). During the Kimmeridgian, marine connections to the Arctic, 

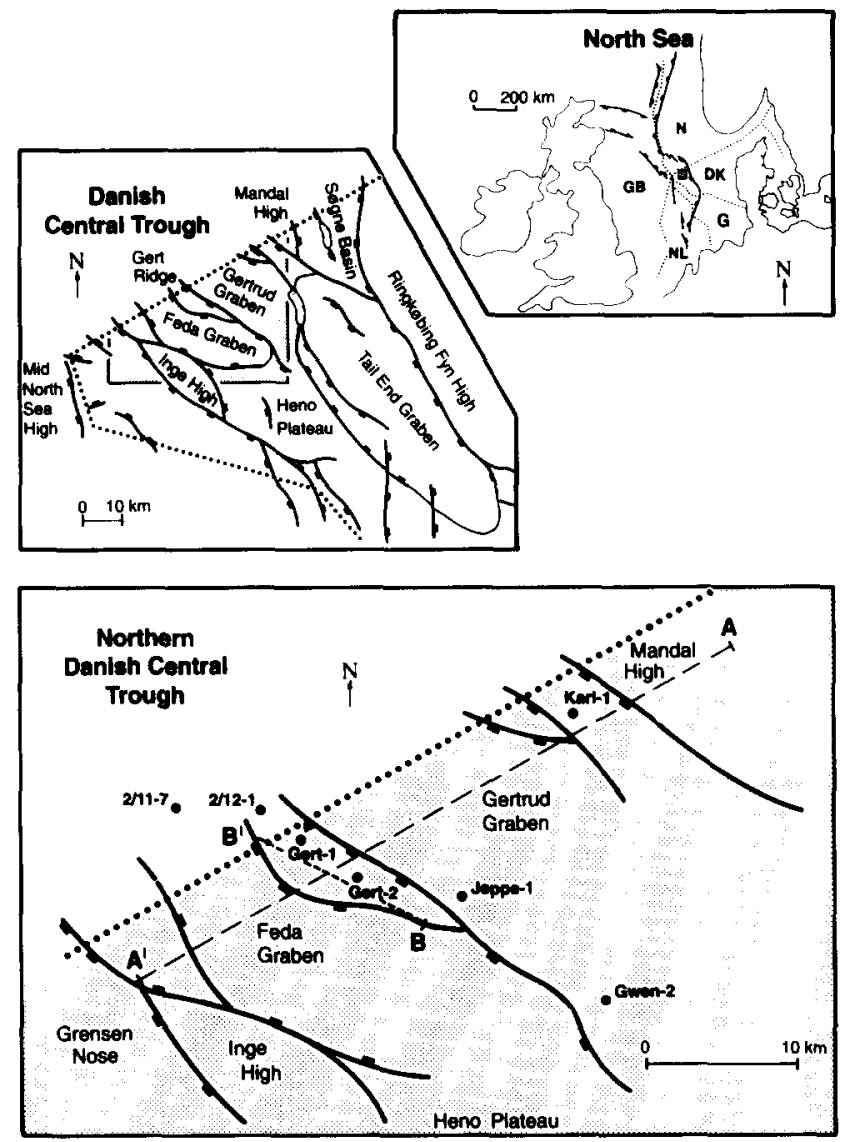

Figure 1 Structural outline of the Danish Central Trough, with location of wells, geosection $\left(A^{\prime}-A\right)$ and seismic section $\left(B^{\prime}-B\right)$

the Central Atlantic and the Tethys oceans were established (Ziegler, 1982, 1988, 1990; Gage and Doré, 1986; Doré and Gage, 1987; Hallam, 1988).

\section{Stratigraphy}

The Jurassic to lowermost Lower Cretaceous succession of the investigated area lies unconformably upon Carboniferous, Permian and Triassic rocks, and is generally conformably overlain by Lower Cretaceous sediments (Figure 2). The lower part of the Jurassic succession consists of aggrading back-barrier and transgressive upper shoreface sandstones of the 'basal sandstone unit' (Figure

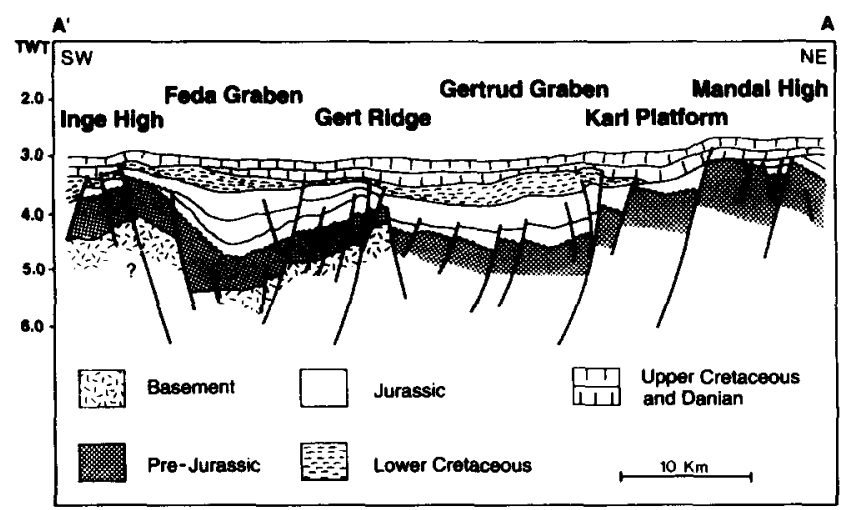

Figure 2 Geosection perpendicular to the axis of the northern part of the Danish Central Trough. Modified from Damtoft $e t$ al. (1992). For location of geosection see Figure 1
3) (Bergan et al., 1989). It is overlain by offshore claystones of the Lola Formation (Figure 4) (Jensen et al., 1986), which is equivalent to the Norwegian Haugesund Formation and the British Heather Formation (Figure 3). The Lola Formation is overlain by regressive and early transgressive lower to middle shoreface sandstones of the Heno Formation (Jensen et al., 1986). The Heno Formation is roughly equivalent to the Fulmar Formation in the UK sector and has many similarities with the 'Heno equivalent' and the Ula Formation of the Norwegian Sector (Bergan et al., 1989).

During continued transgression, up to $2 \mathrm{~km}$ of offshore claystones of the Farsund Formation were deposited (Vollset and Doré, 1984). They constitute the remaining part of the Jurassic succession in the Danish Central Trough and correlate with the Kimmeridge Clay Formation of the UK sector (Figure 3). The Farsund Formation is overlain by Upper Ryazanian calcareous, mudstone-dominated sediments of the Cromer Knoll Group, deposited in an open marine, well-oxygenated environment (Jensen et al., 1986; Michelsen et al., 1987). The transition from the Farsund Formation to the Cromer Knoll Group represents the continuation of the regional transgression (Michelsen et al., 1987).

Previously, the 'basal sandstone unit' has been referred to the latest Callovian-Oxfordian (Bergan et al., 1989), the Lola Formation to the Late Callovian-Kimmeridgian and the Heno Formation to the Middle Oxfordian-Kimmeridgian (Jensen et al., 1986). Söderström et al. (1991) referred the 'basal sandstone unit' to the Middle Callovian-Early Kimmeridgian, whereas the Lola and Heno Formations were referred to the Middle-Upper Kimmeridgian. The Farsund Formation has been referred to the Kimmeridgian-Volgian (Vollset and Doré, 1984) and to the Kimmeridgian-Ryazanian (Heilmann-Clausen, 1987; Poulsen, 1991).

\section{Structural setting}

The study area covers the Feda and Gertrud Grabens. The structural development of these grabens is important for the understanding of the evolution of the Upper Jurassic sediment package (see Söderström et al., 1991; Sundsbø and Megson, 1993; Rasmussen, 1995). The Feda and Gertrud Grabens both formed in an overall extensional tectonic regime, but their development was not synchronous. Three tectonic phases were recognized by Rasmussen (1995):

1. By the early Late Kimmeridgian, subsidence along $\mathbf{N}$ $\mathrm{S}$ trending faults characterized the initial evolution of the Feda Graben (Figure 5a). At this time, most of the Gertrud Graben area formed a plateau with little or no fault-controlled subsidence. The southern part of the study area represented a saddle-like feature between the Feda Graben towards the north and west and the Heno Plateau and the Tail End Graben towards the south and east.

2. After a period of tectonic quiescence, the second phase in the structural evolution was initiated by activation of NW-SE striking normal faults during the latest Late Kimmeridgian resulting in renewed subsidence of the Feda Graben (Figure 5).

3. The third faulting phase, which occurred during the 
Upper Jurassic reservoir sandstones: P. N. Johannessen et al.

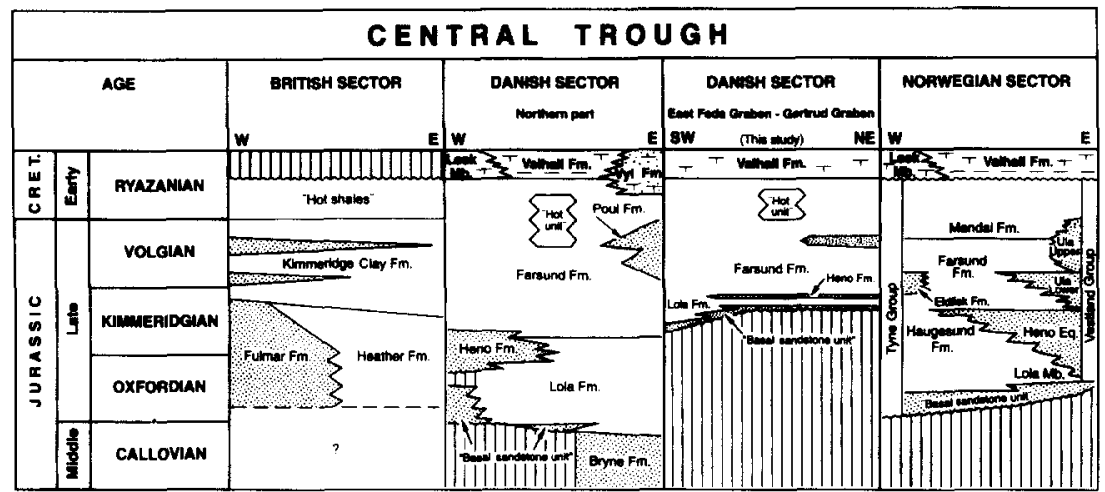

Figure 3 Correlation chart for the Middle Jurassic to Early Cretaceous of the Central Trough. Modified from Johnson et al. (1986), Jensen et al. (1986), Michelsen and Wong (1991) and Bergan et al. (1989)

early Volgian-early Cretaceous, was in many ways a repetition of the second. Fault-controlled subsidence occurred along NW-SE striking faults in an overall extensional regime, not only along the boundary faults of the Feda Graben, but also along faults south of the Mandal High, causing the main subsidence of the Gertrud Graben (Figure 5). Clockwise rotation of the
Feda Graben fault block resulted in compression and thrusting in the Gert area. Further south, near the Gwen-2 well, uplift also occurred along the Gert Fault, but here as footwall uplift along a normal fault. Due to this complex tectonism, areas along the main fault were uplifted and exposed to erosion while deposition still occurred within the graben areas.

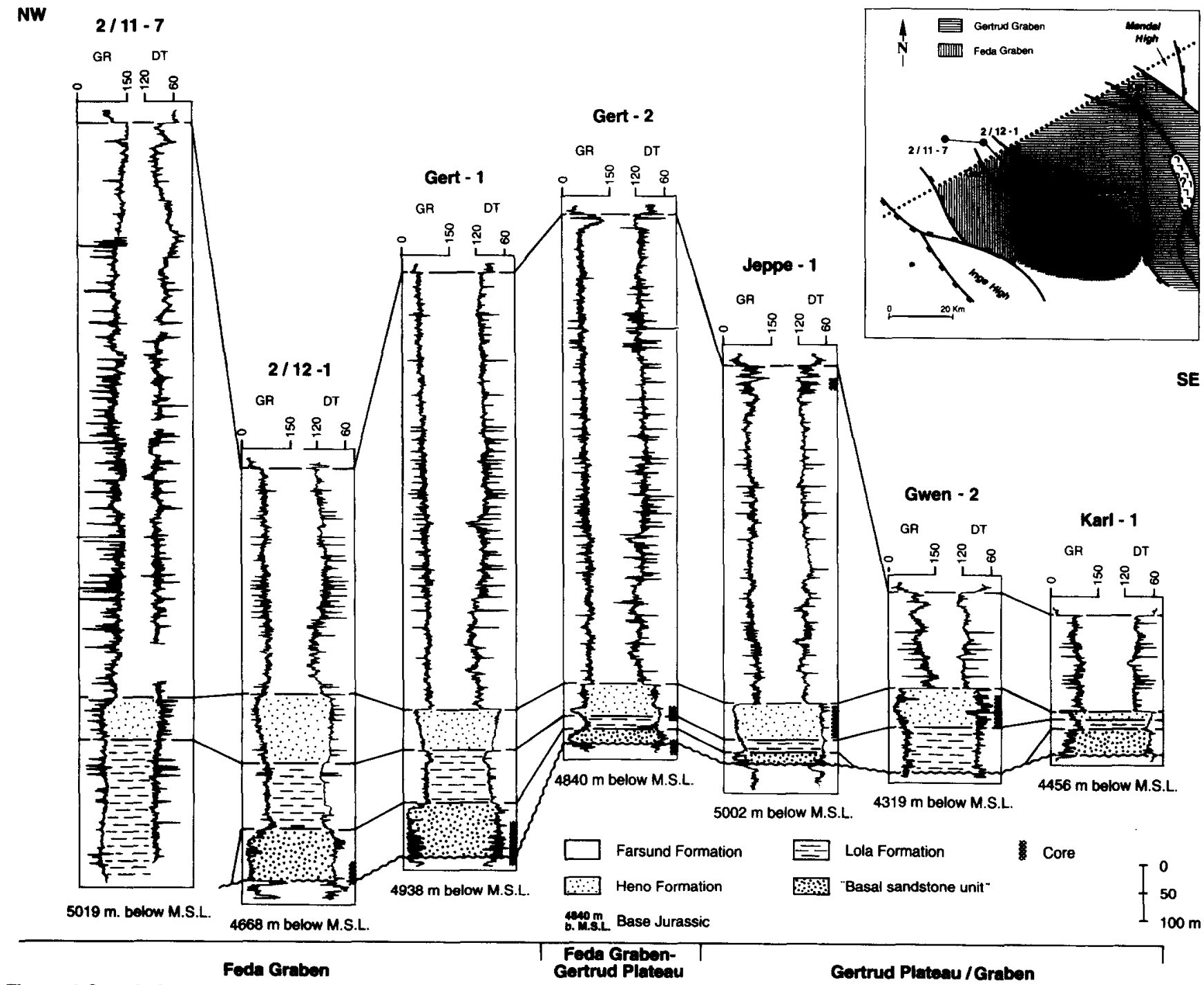

Figure 4 Correlation of Formations within the Upper Jurassic-Lower Cretaceous section of the Feda Graben and the Gertrud Plateau/ Graben. For location of wells see Figure 1 

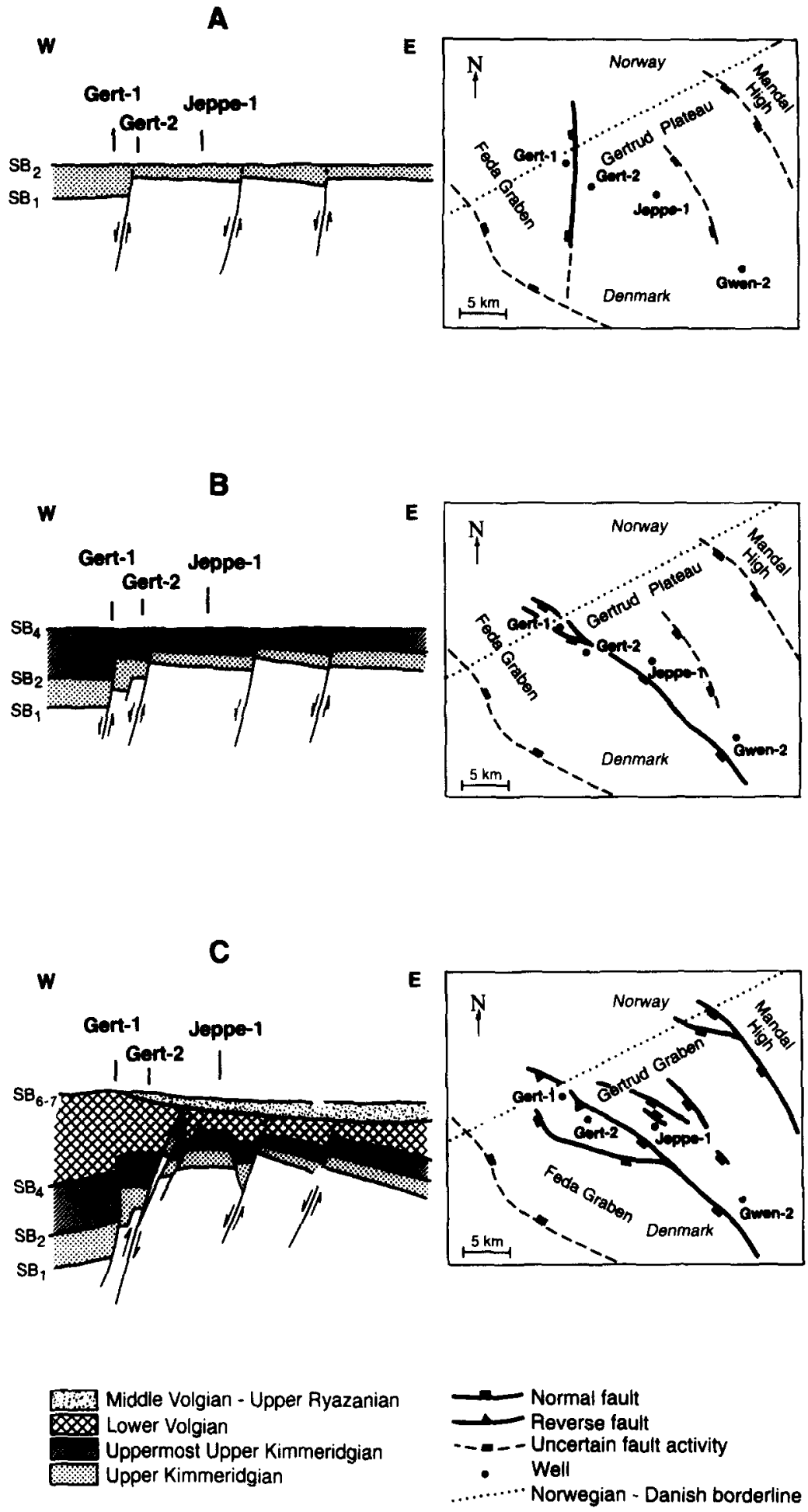

Figure 5 Structural evolution of the eastern part of the Feda Graben and the Gertrud Plateau/Graben

\section{Biostratigraphy}

The age of the investigated well sections has been determined on the basis of the dinoflagellate cyst content (Figure 6). Due to deep burial of the investigated intervals, the palynomorphs are in a very poor state of preservation. Furthermore, only a few age-diagnostic dinoflagellate cyst species occur in the marginal marine sandstone intervals. However, close and selective sampling has resulted in a relatively detailed subdivision of the well-sections.

The reservoir sandstones of the 'basal sandstone unit' and the Heno Formation (Sequence 1 and part of Sequence 2, see below), were deposited within the Late Kimmeridgian Mutabilis Chronozone. These results indicate that the reservoir sandstones are considerably younger than previously suggested (Jensen et al., 1986; Bergan et al., 1989; Söderström et al., 1991; Johannessen and Andsbjerg, 1993).

In general, the Farsund Formation, comprising the interval from the Upper Kimmeridgian to Ryazanian, is fully represented in the studied wells. However, in the 
Upper Jurassic reservoir sandstones: $P$. N. Johannessen et al.

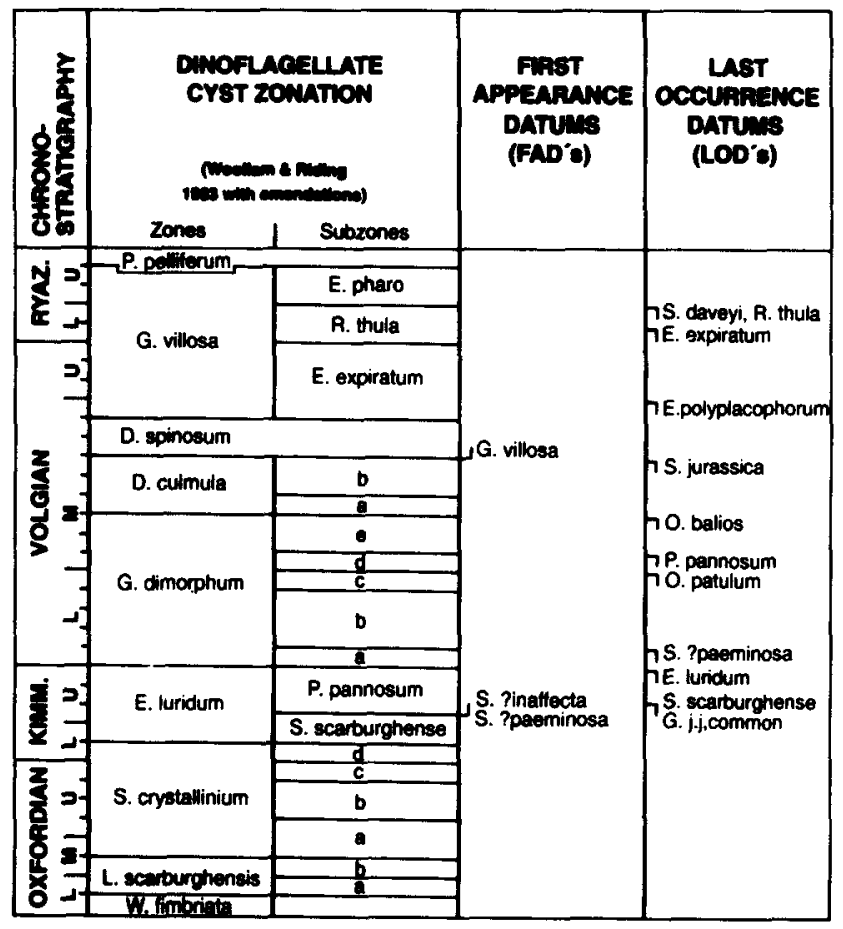

Figure 6 Stratigraphically important first appearances (FAD's) and last occurrences (LOD's) of dinoflagellate cysts, used for dating and correlation

Gert-1 well, the upper Middle Volgian-Ryazanian part of the Farsund Formation is missing, probably due to uplift and erosion during tectonic phase 3 .

\section{Depositional environments}

\section{Back-barrier deposits}

Characteristics. This facies assemblage is typified by the cored lowermost $56 \mathrm{~m}$ of the 'basal sandstone unit' in the Gert-1 well. It consists of interbedded fine-grained sandstones and claystones with coal beds, $2-15 \mathrm{~cm}$ thick. The fine-grained sandstones are commonly thoroughly bioturbated and/or disturbed by water-escape structures such that primary sedimentary structures are unrecognizable. Ophiomorpha burrows, rootlets and coal fragments are typical features of the cored section (Figure 7). The kerogen content of the sandstone beds is composed solely of black, oxidized wood particles, whereas that of the claystone beds and laminae is strongly dominated by terrestrially-derived particles, such as brown and black wood, cuticle, spores, and pollen. Reworked Carboniferous spores and pollen are common. Marine dinoflagellate cysts are scarce $(0-3 \%$ of total palynomorphs; Figure 7).

Coarsening-to fining-upward successions, 3-8 $\mathrm{m}$ thick, are recognized. The lower, coarsening-upward portion consists mainly of Ophiomorpha burrowed siltstones and fine-grained sandstones showing faint parallel bedding or low-angle cross-stratification, commonly associated with water escape structures. The overlying fining-upward portion consists of cross-bedded or low-angle crossstratified fine- or medium-grained sandstones, overlain by structureless fine-grained sandstones, siltstones and claystones, locally capped by coal beds, $2-15 \mathrm{~cm}$ thick. Such fining-upward successions are often associated with Ophiomorpha burrows, water escape structures and rootlets.
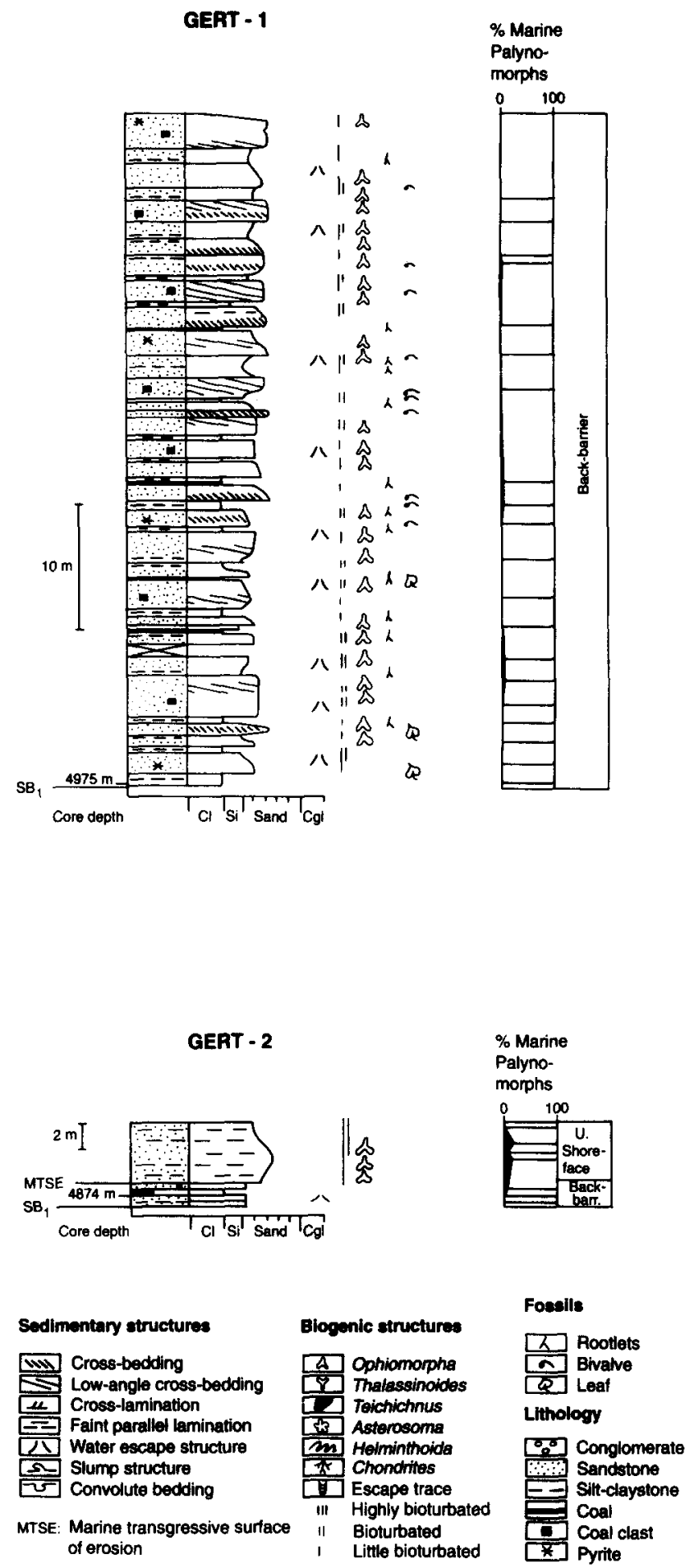

Figure 7 Sedimentological core logs from the 'basal sandstone unit' of the Gert-1 and Gert-2 wells. $\mathrm{SB}_{1}$ : composite sequence boundary

Interpretation. A marginal marine setting is indicated by the association of rootlets and coal beds together with bioturbated sediments with Ophiomorpha. The kerogen indicates a low-salinity, nearshore setting with a high input of terrestrial material. The small number of dinoflagellate cysts, and the dominance of a single genus, Sentusidinium, indicate a low salinity environment (NoeNygaard et al., 1987, Smelror and Leereveld, 1989). The association of restricted marine and non-marine environments, suggests deposition in a back-barrier setting.

The coarsening-upward units were probably deposited by prograding mouth bars, near the bay head shoreline. 
The fining-upward successions were deposited within channels by migrating mega-ripples or bars. The overlying more or less structureless fine-grained sandstones, siltstones and claystones represent the passive fill of the abandoned channel. The thin coal beds, associated with underlying rootlets, represent the final phase of abandonment. The occurrence of Ophiomorpha within the sandstones of the passive channel fill may indicate some marine influence. The channels are interpreted as distributary channels that dissected previously deposited mouth bars.

\section{Shoreface sandstones and conglomerates}

The upper part of the 'basal sandstone unit' consists of transgressive shoreface sandstones that overlie backbarrier sediments and are overlain by offshore claystones of the Lola Formation (Figure 4). The Heno Formation comprises regressive-transgressive shoreface sandstones that overlie the offshore claystones of the Lola Formation and are overlain by the offshore claystones of the Farsund Formation. These two shoreface units are described separately.

\section{Transgressive shoreface sandstones}

Characteristics. The lower part of the cored section of the 'basal sandstone unit' in the Gert-2 well consists of very fine-grained back-barrier sediments, abruptly overlain by $4 \mathrm{~m}$ of fine- and medium-grained faintly parallellaminated, bioturbated sandstones characterized by abundant Ophiomorpha burrows (Figures 4 and 7). The percentage of marine palynomorphs $(0-16 \%$ of total palynomorphs) is high compared with the back-barrier succession in the Gert-1 and Gert-2 wells (see above).

Low gamma values and high sonic velocities characterize the upper part of the 'basal sandstone unit'. They are followed upwards by a stepwise increase in gamma radiation and corresponding decrease in sonic velocity in the Gert-1, Gert-2, Jeppe-1, Gwen-2 and 2/12-1 wells (Figure 4).

Interpretation. The trace fossil assemblage and the palynofacies data together indicate a marine nearshore environment with a high input of terrestrial material. The uppermost clean marine sandstones in the Gert-2 well were probably deposited within the upper shoreface. The sharp boundary between back-barrier sediments and the overlying shoreface sandstones is thus interpreted as a marine transgressive surface of erosion.

The gamma ray and sonic log trends of the Gert-2, Gert-1 and Jeppe-1 wells indicate clean sandstones that fine-upwards in a stepwise manner. They are also interpreted as a backstepping succession of shoreface sandstones. Much of the 'basal sandstone unit' in the 2/12-1 well has been interpreted in a similar way (Söderström et al., 1991). In all wells the transgressive sandstones overlie back-barrier sediments.

The backstepping shoreface sandstones are overlain by offshore claystones of the Lola Formation, sandwiched between the 'basal sandstone unit' and the overlying Heno Formation.

\section{Regressive-transgressive shoreface sandstones}

Characteristics. The Heno Formation is characterized by an upward coarsening, 15-70 m thick, very fine- to medium-grained sandstone succession overlain by an

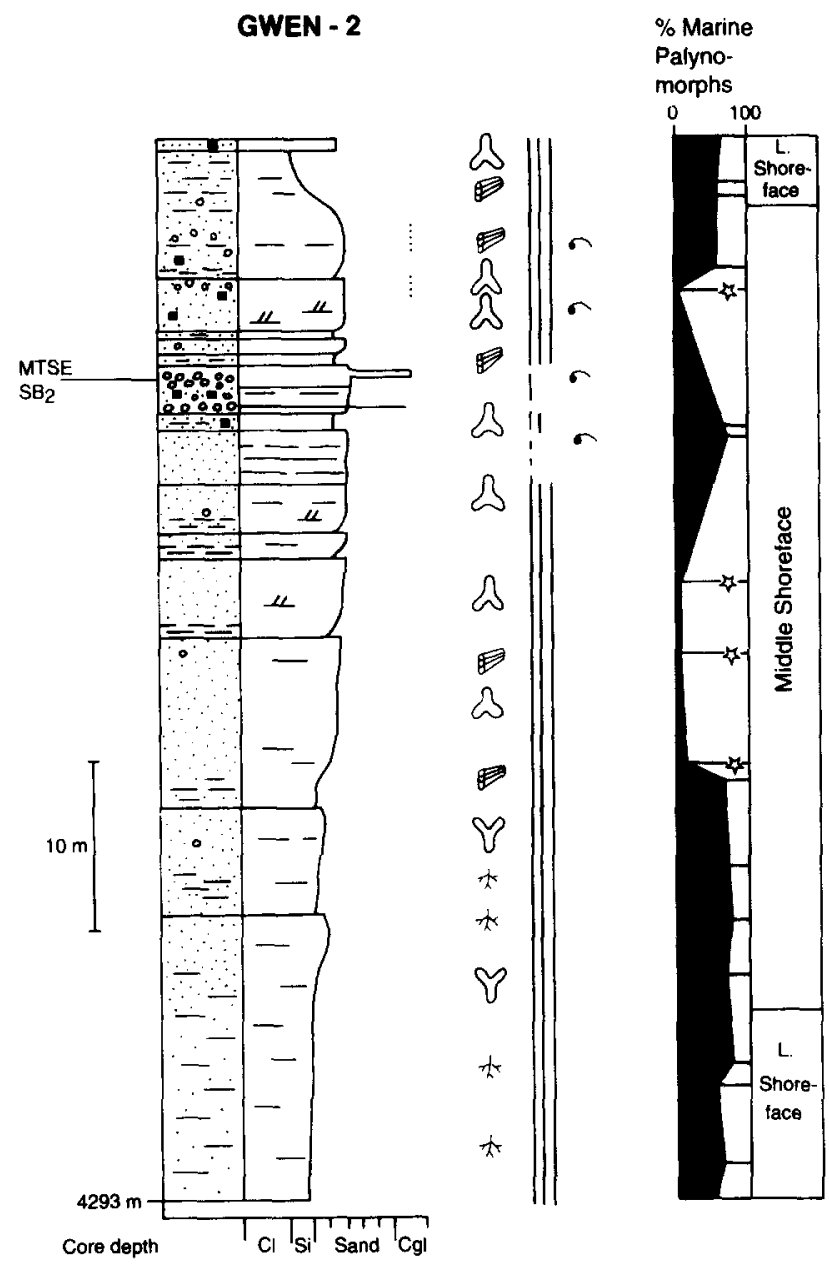

Figure 8 Sedimentological core log from the Heno Formation of the Gwen-2 well. Asterisks indicate samples where the percentage of marine palynomorphs probably is surpressed due to reworked Lower Jurassic clay clasts $(2 \mathrm{~mm}$ in diameter) containing high amounts of terrestrial palynomorphs. $\mathrm{SB}_{2}$ : sequence boundary no. 2

upward fining unit, 15-30 m thick, composed of mediumto very fine-grained sandstone (Figure 4). A conglomeratic unit is present in Gwen-2 $(0.5 \mathrm{~m}$ thick) and Jeppe-1 (3 m thick) abruptly overlying the fine- to medium-grained sandstones of the upward coarsening succession (Figures 8 and 9).

The sandstones and the conglomeratic unit are typically bioturbated to such a degree that primary sedimentary structures are unrecognizable. The trace fossils Helminthoida, Chondrites, Teichichnus, and Thalassinoides have been identified. Faint parallel bedding and cross-lamination are seen locally. Seven upward coarsening units, 2-15 m thick, characterize the overall $45 \mathrm{~m}$ thick, coarsening upward sandstone succession in Gwen-2 (Figure 8). The two uppermost coarsening upward units consist of parallel laminated, medium-grained sandstone beds $(15-30 \mathrm{~cm}$ thick); these are overlain by the conglomeratic unit (Figure 8 ).

Quartz clasts, $0.5-3 \mathrm{~mm}$ in diameter and often well rounded and spherical, commonly occur scattered within the bioturbated sandstones in the Jeppe-1, Gwen-2 and Gert- 2 wells. The conglomerates are typically matrixsupported, but a few clast-supported conglomerate beds, $2-4 \mathrm{~cm}$ thick, occur in the Gwen- 2 and Jeppe- 1 wells. In both cases the clasts are $0.5-2 \mathrm{~cm}$ in diameter and the 


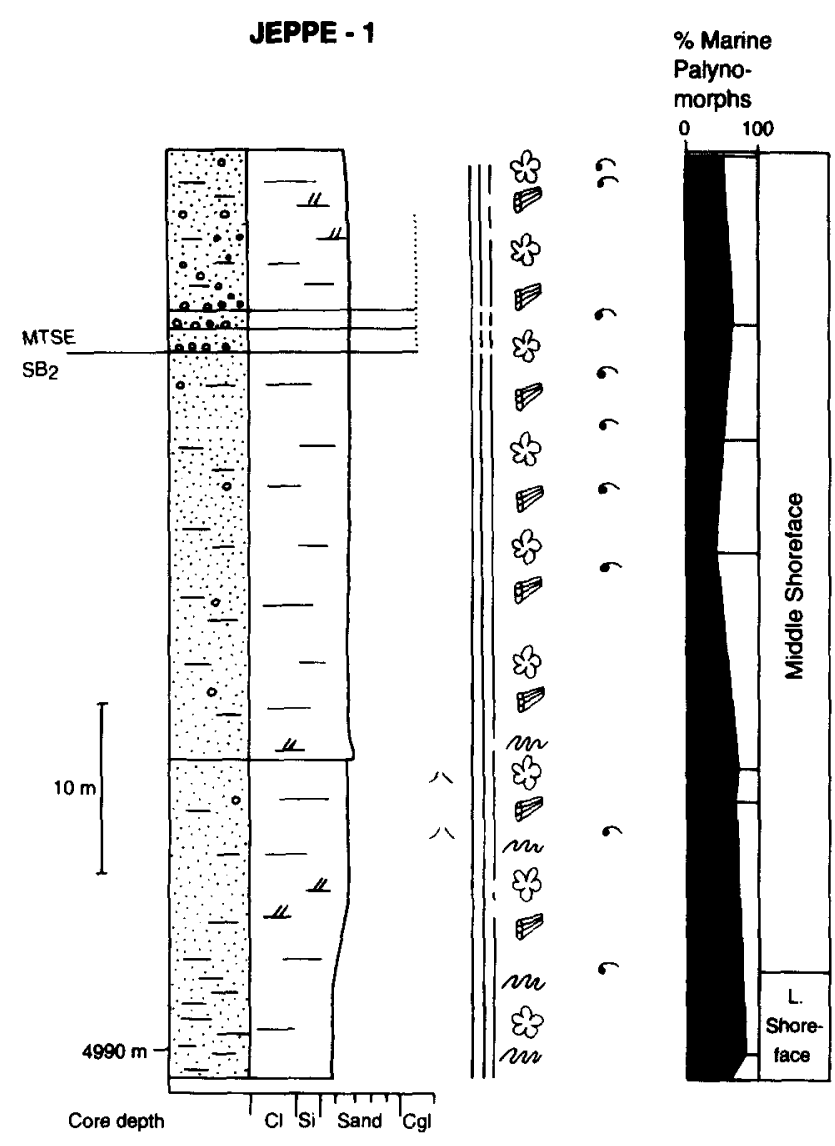

GERT - 2
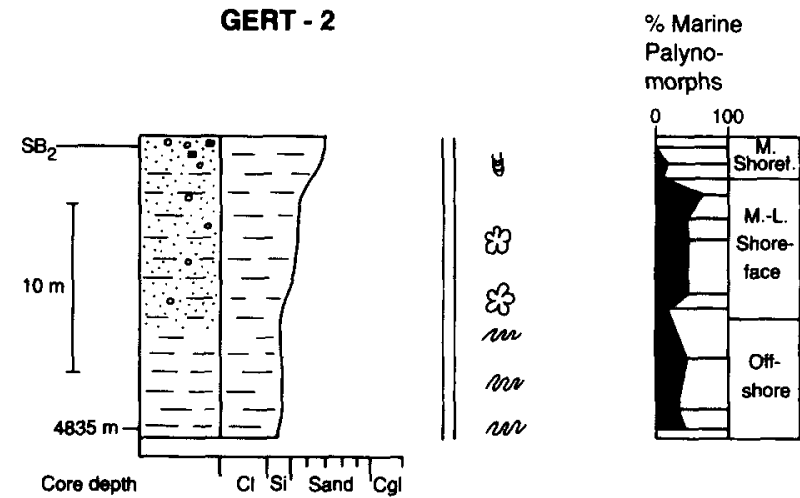

Figure 9 Sedimentological core logs from the Heno Formation of the Jeppe-1 and the Gert-2 wells. $\mathrm{SB}_{2}$ : sequence boundary no. 2

matrix consists of fine to medium-grained sandstone and contains pyrite, coal fragments and bivalve shells.

The kerogen assemblages are dominated by brown and black wood. The relative abundance of dinoflagellate cysts is high (up to $77 \%$ of the total palynomorph assemblage; Figures 8 and 9). In three samples from the Gwen2 well, marine palynomorphs are poorly represented (4$15 \%$ of the total palynomorph assemblage; Figure 8 ). Careful examination of these samples, however, shows that they contain small ( $1 \mathrm{~mm}$ in diameter) clay clasts with large quantities of reworked Lower Jurassic terrestrial palynomorphs, which 'dilute' the assemblages resulting in the low relative percentages of Upper Jurassic marine palynomorphs.

Interpretation. The intense bioturbation, the trace fossil assemblage, and the high relative abundance of marine palynomorphs indicate that the sandstones and the conglomeratic unit were deposited within a well-oxygenated, marine shoreface environment. The abundance of coal clasts, especially in the conglomerates of Gwen-2, supports this interpretation. The kerogen assemblage indicates marine conditions with normal salinities and a significant terrestrial influence. The upward-coarsening succession represents the progradation of the lower to middle shoreface, while the fining-upward succession represents subsequent backstepping of the middle to lower shoreface. The conglomeratic unit is interpreted as having been deposited at the turnaround point during maximum regression.

The few preserved cross-laminae indicate the presence of migrating small-scale ripples. The parallel laminated sandstone beds in the Gwen-2 well, underlying the conglomeratic unit, may have been deposited under upper flow regime conditions during major storms. Sedimentation rates were either sufficiently high or the density of burrowing organisms was reduced, resulting in preservation of primary sedimentary structures.

The bioturbated sandstones that dominate the Heno Formation are similary interpreted as the deposits of storm-generated currents that transported sand from the beach out to the middle and lower shoreface. The scattered matrix-supported quartz clasts recognized in the Gert-2, Jeppe-1 and Gwen-2 wells were probably deposited on scoured surfaces by storm currents that swept across the sea-bottom; the clasts were subsequently dispersed in the sediment by the burrowing infauna. The seven upward coarsening intervals within the overall progradational shoreface sandstones in the Gwen- 2 well may be interpreted as smaller scale prograding shoreface units.

The clasts in the conglomerates at the base of the conglomeratic unit in the Gwen-2 and Jeppe- 1 wells are, on average, much larger than the outsized clasts within the upward-coarsening shoreface sandstones. The conglomerates were thus not derived exclusively by reworking at the marine transgressive surface of erosion. They were probably originally deposited during maximum regression on a storm dominated shoreface or within fluvial channels. There is no evidence of subaerial exposure such as palaeosols, coal beds, rootlets and desiccation cracks, suggesting that the conglomerates were reworked during subsequent transgression.

In most wells (e.g. Gert-2, Jeppe-1 and Gwen-2) the backstepping upper part of the shoreface sandstones is abruptly overlain by offshore claystones of the Farsund Formation. In contrast, in wells $2 / 12-1$ and $2 / 11-7$, farthest out in the Feda Graben (Figure 4), the shoreface sandstones gradually fine upwards into the overlying offshore claystones of the Farsund Formation.

The facies of the Heno Formation are very similar to those described from the Upper Jurassic Ula Formation (eastern Central Graben, Norway; Taylor and Gawthorpe, 1993), the Upper Jurassic of the 'Heno Equivalent' (eastern Central Graben, Norway; Bergan et al., 1989 ) and the Upper Jurassic Fulmar Formation (western Central Graben, UK; Johnson et al., 1986; Howell et al., 1996). 


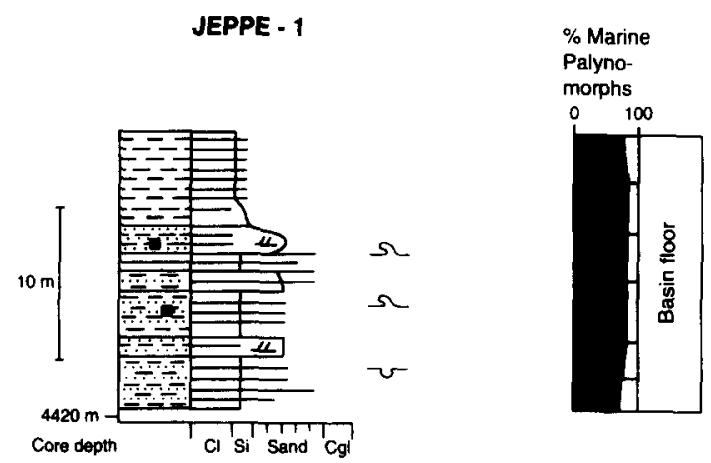

Figure 10 Sedimentological core log from the Farsund Formation and the 'hot unit' in the Jeppe-1 well

\section{Offshore claystones}

Characteristics. The Lola and Farsund Formation are characterized by claystones with varying content of organic matter, interbedded with thin laminae of dolomite, siltstone and fine-grained sandstone (Figure 4) and can be correlated to all the wells in the study area (Figure 4). The claystones contains high amounts of dinoflagellate cysts. The claystones of the Lola Formation contain larger amounts of terrestrially derived material than the Farsund Formation (Jensen et al., 1986; Michelsen et al., 1987).

Interpretation. The claystones were deposited in a lowenergy offshore marine setting. The claystones of the Lola Formation were probably deposited nearer to the sediment source area than those of the succeeding Farsund Formation, indicating an overall transgressive trend.

\section{Turbidite sandstones}

Characteristics. The uppermost part of the Farsund Formation in the Jeppe-1 well consists of a $45 \mathrm{~m}$ thick unit of interlaminated, sandstone-claystone, $12 \mathrm{~m}$ of which have been cored (Figures 4 and 10). Two different types of sandstones are recognized: (1) $1-5 \mathrm{~cm}$ thick erosionally based, normally graded, medium to fine-grained sandstones showing parallel or cross-lamination, and (2) $5-30 \mathrm{~cm}$ thick erosionally based, massive, poorly sorted beds of matrix-supported, fine to coarse-grained muddy sandstones with rip-up clasts of claystone, up to $5 \mathrm{~cm}$ in diameter. Loading and water escape structures are common in both types of sandstones. Slump sheets incorporating both facies are common.

The claystone laminae and beds are organic-rich. The upper $6 \mathrm{~m}$ of the cored section, form the lower part of the 'hot unit' of Jensen et al. (1986). They consist of parallel-laminated, non-bioturbated claystones and normally graded siltstones, and show very high gamma ray log readings (144 API) (Figure 4). The relative abundance of dinoflagellate cysts is the highest recorded in this study (up to $80 \%$ of the total palynomorph assemblage) (Figure 10 ).

Above the 'hot unit' in the Jeppe-1 well an approx. $20 \mathrm{~m}$ thick interval shows low gamma ray readings increasing upwards, representing an upward fining sandstone succession interbedded with claystones (Figure 11).

The upper part of the Farsund Formation in the Gert2 well is referred to the 'hot unit'. It shows high gamma ray, resistivity, TOC and $\mathrm{HI}$ values, testifying to the presence of large amounts of organic matter (Figure 12).
The high gamma ray interval at the same stratigraphical level in the Gwen-2 well is also referred to the 'hot unit'.

Interpretation. The high relative abundance of marine palynomorphs and the total lack of bioturbation in the cored section of the Jeppe-1 well, indicate that the sediments were deposited under anoxic bottom conditions.

The thin erosionally based, graded sandstones were deposited from waning turbidity currents; they typically show Bouma $\mathrm{B}$ and/or $\mathrm{C}$ divisions. The very poor sorting of the thicker sandstone beds suggests deposition from cohesive debris flows (Lowe, 1979).

The organic-rich claystones of the 'hot unit' in Jeppe1 were deposited in a low-energy environment in which clay and organic matter settled out of suspension. The normally graded siltstones of the 'hot unit' were deposited from low density turbidity currents. The large amounts of preserved organic matter testify to anoxic bottom conditions.

\section{Sequence stratigraphy}

The Jurassic section of the study area is very deeply buried and the seismic resolution is limited. Sequence stratigraphic key surfaces, systems tracts and sequences are therefore defined primarily on the basis of sedimentological core analysis and petrophysical log patterns. These are then utilised in seismic interpretation.

\section{Sequence 1}

The lowermost sequence lies unconformably upon Carboniferous, Permian, and Triassic rocks; the base of the sequence is thus a composite sequence boundary: $\mathrm{SB}_{1}$ (Figures 11 and 13). Sequence 1 consists of a transgressive systems tract followed by a highstand systems tract.

\section{Transgressive systems tract}

The transgressive systems tract includes the back-barrier deposits and the shoreface sandstones of the "basal sandstone unit' with a characteristic backstepping upper part, and the offshore claystones of the Lola Formation (Figures 4 and 11 ). The high gamma ray readings and high resistivities displayed by the Lola Formation probably reflect a high content of organic matter, as demonstrated for the Farsund Formation (Figure 12). This suggests that the clastic source area had moved progressively further away, allowing organic matter to accumulate on the sea floor from suspension with less dilution from terrestrial siliciclastic sediments. The claystone succession thus represents continued transgression. The most organic-rich interval is interpreted as a condensed section including the maximum flooding surface MFS $_{1}$ (Figure 11).

The lowermost part of sequence 1 of the Gert-1 well consists of aggrading back-barrier sediments, $60 \mathrm{~m}$ thick, overlying the composite sequence boundary, $\mathrm{SB}_{1}$. They are capped by the base of the clean coarse-grained shoreface sandstones marking a landward shift in facies. The boundary between the back-barrier sediments and the overlying shoreface sandstones is interpreted as a marine transgressive surface of erosion (Figures 7 and 11). A seismic marker tied to the clean shoreface sandstones, onlaps the composite sequence boundary, $\mathrm{SB}_{1}$, from the deeper to the more shallow part of the Feda Graben, towards the Gertrud Plateau (Figures 11 and 13). This indicates that the marine transgressive surface of erosion 
Upper Jurassic reservoir sandstones: P. N. Johannessen et al.
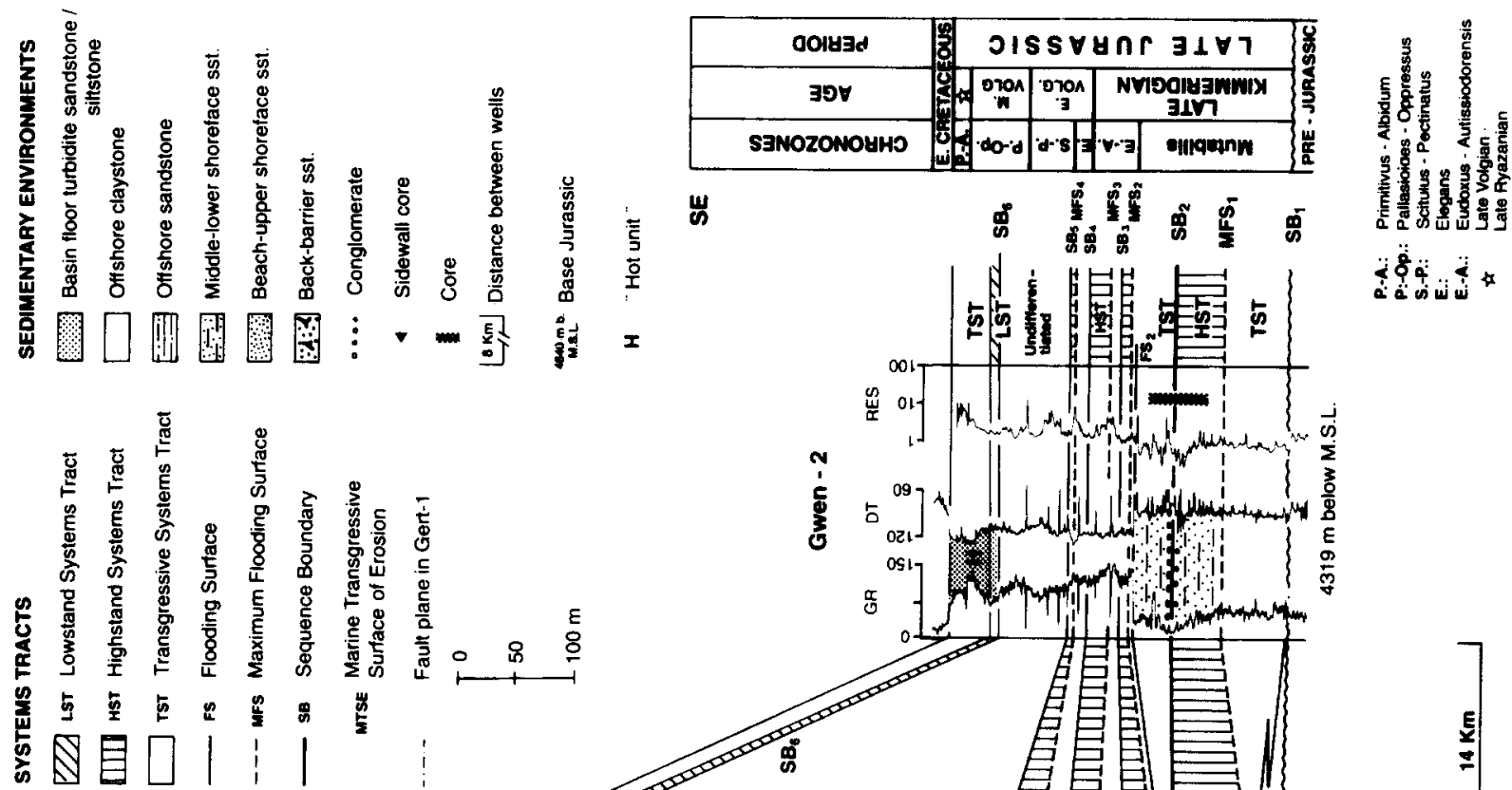


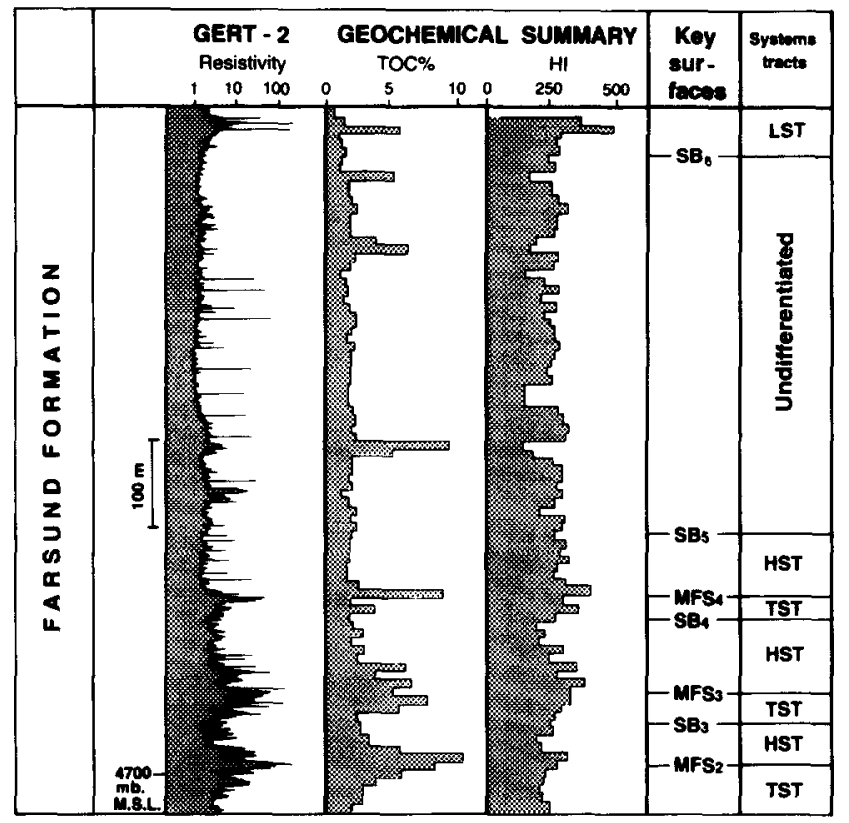

Figure 12 Geochemical profile of the Upper Jurassic of the Gert2 well, modified from Damtoft et al. (1992). There is a very good correlation between high resistivity and large content of organic matter (TOC). In the lower part of the Farsund Formation high TOC corresponds to a high hydrogen index $(\mathrm{HI})$, indicating that organic matter is mainly marine derived. SB: sequence boundary. MFS: maximum flooding surface. TST: transgressive systems tract. HST: highstand systems tract. MFS $_{4}$ corresponds to a seismic marker which can be traced regionally in the Feda Graben

in Gert-1 is older than the 'basal sandstone unit' in Gert2 and Jeppe- 1 .

The 2/12-1 well situated in the same structural position as the Gert-1 well, on the down-thrown side of a normal fault, is characterized by aggrading shoreface foreshore sandstones, $71 \mathrm{~m}$ thick (Söderström et al., 1991), corresponding to the aggraded back-barrier sediments of the Gert- 1 well. The aggrading sediments were thus deposited while the hanging wall subsided during the Late Kimmeridgian tectonic phase 1 , creating new accommodation space at a high rate. At the same time, footwall uplift of the Gertrud Plateau may have resulted in an enlarged source area and increased sediment input to the Feda Graben. Carboniferous sandstones exposed on the upthrown side of the fault between the Gert-1 and Gert2 wells (and cored in Gert-2) may have acted as an additional source for the thick transgressive sandstones of the 'basal sandstone unit' of Gert-1 and 2/12-1, as suggested by the presence of reworked Carboniferous palynomorphs in the sediment pile.

The upper part of the shoreface sandstones in Gert-1 and 2/12-1 backsteps to be overlain by offshore claystones of the Lola Formation (Figures 4 and 11). The transgressive systems tract on the Gertrud Plateau (Gert-2 and Jeppe-1) shows the same vertical succession of facies associations as the 'basal sandstone unit' in the Feda Graben (Gert-1 and 2/12-1), but is only $20 \mathrm{~m}$ thick; this is probably due to lower subsidence rates resulting in decreased accommodation space (Figure 11). The Gert2 and Jeppe-1 wells are characterized by back-barrier sediments, resting on the composite sequence boundary $\mathrm{SB}_{1}$, and overlain by backstepping shoreface sandstones upon a marine transgressive surface of erosion. Offshore claystones of the Lola Formation overlie the shoreface sandstones. The most organic-rich interval is interpreted as a condensed section including a maximum flooding surface which is correlated with the maximum flooding surface in the Feda Graben: MFS $_{1}$ (Figures 11 and 14).

The transgressive systems tract in the southern part of the Gertrud Plateau (Gwen-2) is characterized by a thicker $(63 \mathrm{~m})$ succession of offshore claystones and siltstones of the Lola Formation. The claystones are thick in Gert-1 $(87 \mathrm{~m})$ and Gwen-2, but thin between these wells in Gert-2 $(11 \mathrm{~m})$ and Jeppe- $1(18 \mathrm{~m})$. This may reflect a transgression towards the Gertrud Plateau from the NW from the Feda Graben and from the SE from the Tail End Graben. The thickness variation of the claystones indicates that the southern and northwestern part of the study area experienced larger subsidence rates than the Gertrud Plateau.

\section{Highstand systems tract}

A coarsening upward interval above the $\mathrm{MFS}_{1}$ is interpreted as a prograding wedge of a highstand systems tract

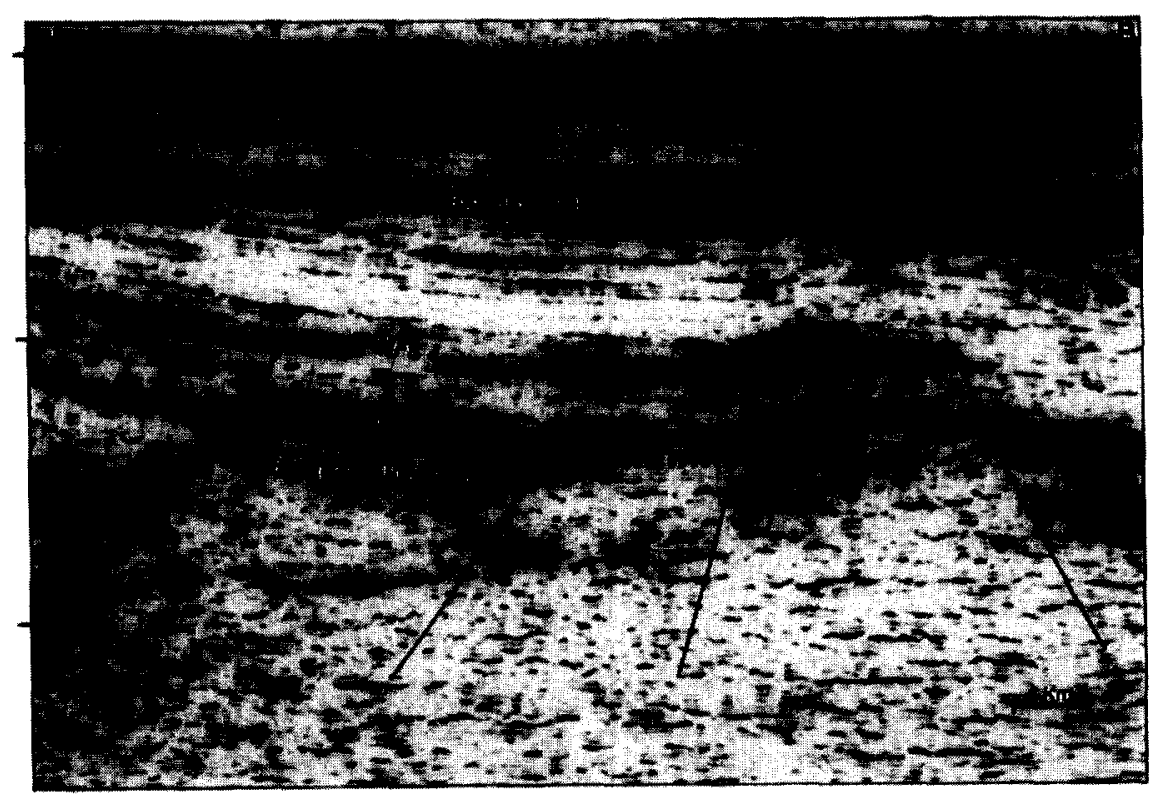

Figure 13 Seismic section from the Feda Graben. For location see Figure 1. Modified from Rasmussen (1995) 

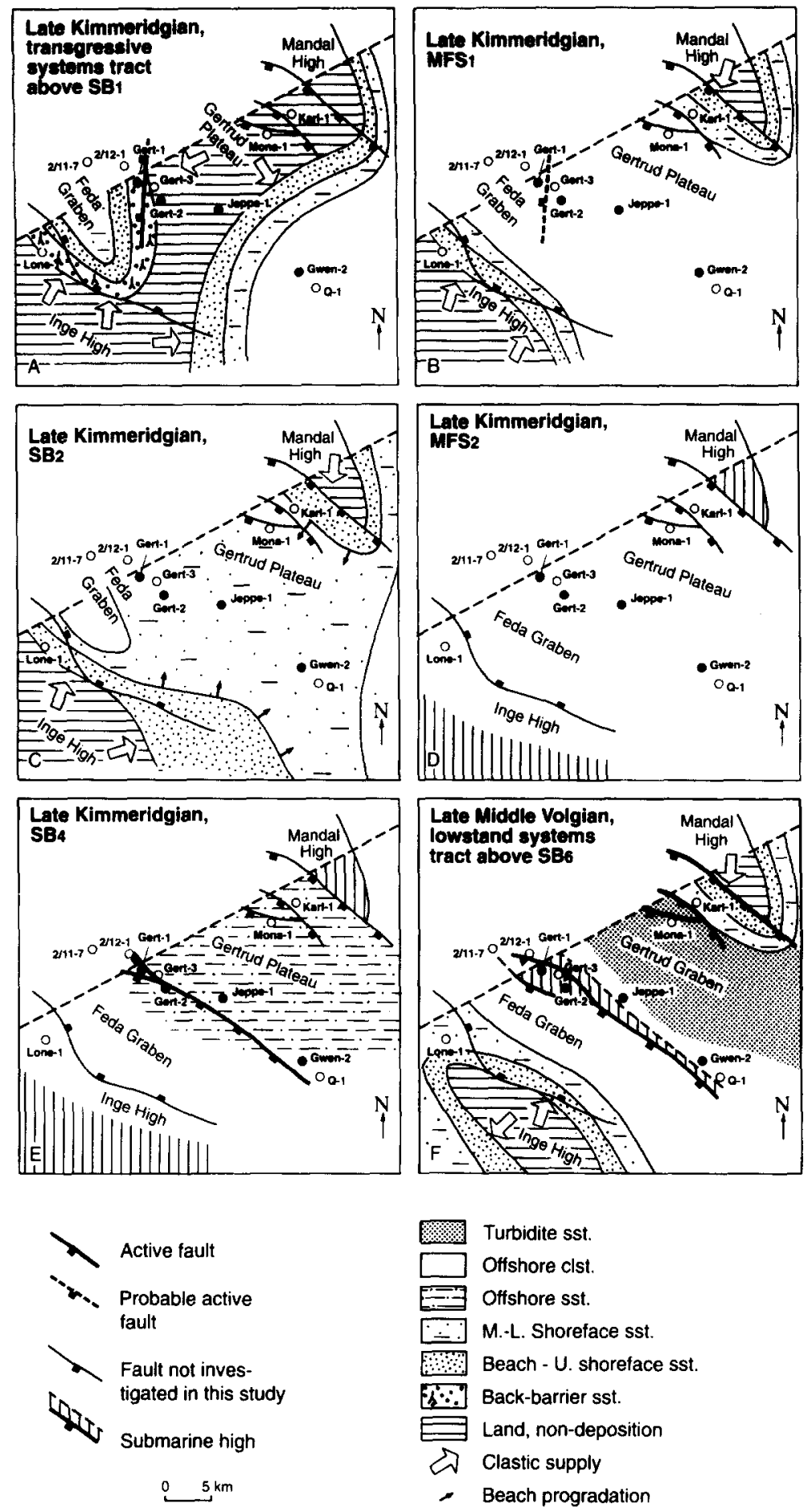

Figure 14 Late Jurassic palaeogeography of the northernmost part of the Danish Central Trough

on the Gertrud Plateau and the marginal areas of the Feda Graben (Figures 11 and 14). Five upward-coarsening intervals, each $2-15 \mathrm{~m}$ thick, recognized in the prograding shoreface sandstones in Gwen-2, are interpreted as parasequences within a prograding parasequence set.

The conglomerates in Gwen-2 and Jeppe-1 on the Gertrud Plateau are interpreted as marine transgressive lags, representing coarse-grained marine storm beds or coarsegrained fluvial sediments reworked by erosive shoreface processes during transgression. The sequence boundary, $\mathrm{SB}_{2}$, and the marine transgressive surface of erosion are amalgamated and occur at the base of the conglomerate; this then defines the top of the highstand systems tract (Figures 8 and 9).

The conglomerates in Gwen-2 and Jeppe-1 may, however, also have resulted from submarine or subaerial erosion of the shoreface due to a fall in relative sea level. If such a fall was large, lowstand shoreface sandstones would have been deposited in the Feda Graben and constitute a good potential reservoir. These postulated lowstand shoreface sandstones must occur south of the 2/117 and 2/12-1 wells in the Feda Graben, as no shoreface sandstones are recognized in these wells (Figure 4). On the contrary, the shoreface sandstones shale out from the Gertrud Plateau towards the Feda Graben. 
Sequence boundary $\mathrm{SB}_{2}$ is placed at the base of the most coarse-grained sandstone in the Gert-2 well (Figure 9). A normal fault probably truncates the upper part of sequence 1 in the Gert-1 well (Figure 11).

\section{Sequence 2}

Sequence 2 consists of a transgressive systems tract and a highstand systems tract.

\section{Transgressive systems tract}

The fining-upward interval immediately above sequence boundary $\mathrm{SB}_{2}$, consists of storm-dominated, middle shoreface sandstones at the base succeeded by lower shoreface sandstones and capped by offshore claystones. The interval is interpreted as a part of a backstepping wedge, belonging to a transgressive systems tract. The sandy basal part of this systems tract is recognized in the Gert-2, Jeppe-1 and Gwen-2 wells (Figure 11). Their absence in the Gert-1 well is attributed to faulting.

In the three wells, middle to lower shoreface sandstones of the transgressive systems tract are abruptly overlain by offshore claystones of the Farsund Formation (Figures 4 and 11). This abrupt landward shift in facies is interpreted as a prominent flooding surface, $\mathrm{FS}_{2}$, which is also recognized on seismic sections (Figures 11 and 13). The marked facies change probably largely reflects an abrupt decrease in energy levels due to a major increase in water depth, but may be partly the result of a sudden cessation of supply from nearby sand source areas (Mandal High and Inge High) as a result of complete drowning of these local highs.

The offshore claystones in all four wells are characterized by increasing resistivity and gamma ray values and decreasing sonic velocities. This indicates an upward decrease in grain-size and an increase in organic matter (Figure 12). The interval with the highest amount of organic matter is interpreted as a condensed section including a maximum flooding surface, $\mathrm{MFS}_{2}$ (Figures 11 and 14 ). This and subsequent condensed sections $\left(\mathrm{MFS}_{2}\right.$, $\mathrm{MFS}_{3}$ and $\mathrm{MFS}_{4}$ ) constitute good oil-prone source rocks (Damtoft et al., 1992).

\section{Highstand systems tract}

The uppermost part of sequence 2 is characterized by upward decreasing resistivity and gamma ray values and increasing sonic velocities reflecting a coarsening-upward trend from offshore claystones to silty claystones (Figure 11). This reflects a progradational offshore wedge and is interpreted as a highstand systems tract. The sequence boundary, $\mathbf{S B}_{3}$, forming the top of the highstand systems tract is placed at the most coarse-grained part of the coarsening-upward interval, representing maximum progradation of the offshore wedge. The very fine grain size of the wedge indicates that only the most distal part of a coarser and thicker sandstone wedge, deposited closer to the basin margin, reached the study area.

\section{Sequences 3 and 4}

Sequences 3 and 4 do not include reservoir sandstones. Both sequences are very similar. They consist of a transgressive and a highstand systems tract, and are described together.

\section{Transgressive systems tracts}

The lowermost part of both sequences is characterized by increasing resistivity and gamma ray readings, accompanied by decreasing sonic velocities. This reflects an upward increase in organic matter indicating deposition within backstepping offshore wedges (Figure 12). The successions are interpreted as transgressive systems tracts. The top of the transgressive systems tracts are defined at the most fine-grained level, coinciding with the highest content of organic matter. These horizons represents maximum flooding surfaces, $\mathrm{MFS}_{3}$ and $\mathrm{MFS}_{4}$ of sequences 3 and 4, respectively (Figures 11 and 12 ).

\section{Highstand systems tracts}

The uppermost part of both sequences is characterized by upward decreasing resistivity and gamma ray values, increasing sonic velocities and an upward decrease in organic matter, suggesting deposition during progradation (Figures 11 and 12). These claystone and siltstone wedges are interpreted as highstand systems tracts. The highstand systems tracts are bounded upward by sequence boundaries $\mathrm{SB}_{4}$ and $\mathrm{SB}_{5}$ at the top of the coarsening upward succession, representing maximum progradation. Cuttings from the coarsest part of the highstand systems tract in sequence 3 in the Gert- 1 and Gert-2 wells contain sand (Figures 11 and 14). The highstand systems tract of sequence 3 is thickest in the Gert1 well $(160 \mathrm{~m})$ in the Feda Graben, thinner in the Gert-2 well $(80 \mathrm{~m})$ and most thinly developed in the Jeppe- 1 and Gwen-2 wells $(25 \mathrm{~m}$ and $17 \mathrm{~m}$ ) on the Gertrud Plateau. This is probably the result of higher subsidence rates in the Feda Graben than on the Gertrud Plateau. The low content of silt and sand in this progradational unit, suggests that the Mandal High and Inge High were still submerged.

\section{Sequence 5}

\section{Undifferentiated systems tracts}

The base of sequence $5, \mathbf{S B}_{5}$, is placed at the top of a prograding offshore claystone-siltstone succession (Figure 11). The remaining part of the Lower-middle Middle Volgian of the Farsund Formation displays no clear log trends and sequence 5 has accordingly not been subdivided into systems tracts. The upper part of this sequence is unconformably overlain by Lower Cretaceous sediments in the Gert- 1 well and overlain by sequence 6 of the Farsund Formation in the Gert-2, Jeppe-1 and Gwen-2 wells.

\section{Sequence 6}

Sequence 6 is recognized in the Jeppe-1, Gwen-2 and the Gert-2 wells within the Gertrud Graben and consists of a lowstand and transgressive systems tract (Figure II). The sequence probably continues into the overlying marly claystones of the Valhall Formation (Figure 3).

\section{Lowstand and transgressive systems tract}

In the Jeppe-1 well, the base of sequence $6, \mathbf{S B}_{6}$, is picked at the sharp base of a succession of thin turbidite sandstones interbedded with organic-rich claystones (Figure II). The sudden influx of sandstones in the offshore clay- 
stones of the Farsund Formation in the upper part of the Jeppe- 1 well, suggests a fall in relative sea level. The sharp-based succession of the turbiditic sandstones and mudstones are thus associated with the lowstand systems tract; the Mandal High and Inge High were probably emergent at this time (Figure 14 ).

Organic-rich claystones characteristic of the 'hot unit' overlie the turbidite sediments in Jeppe-1, Gert-2 and Gwen-2 (Figure 11). The organic-rich claystones were probably deposited during a period of overall transgression, such that organic matter was able to accumulate on the sea floor with progressively less dilution by terrestrial siliciclastic sediments. The organic-rich claystones are therefore interpreted to have been deposited during early transgression and are referred to the transgressive systems tract. These fine-grained sediments of the 'hot unit' correspond in part to the Norwegian Mandal Formation (Jensen et al., 1986) (Figure 3).

The Late Jurassic succession in the Gert-2, Jeppe-1, and Gwen-2 wells is condensed but is presumed to be conformably overlain by the more calcareous finegrained Lower Cretaceous Valhall Formation. Michelsen et al. (1987) interpreted this transition as the result of an overall transgression. It seems likely therefore that the transgressive systems tract recognized in the uppermost Farsund Formation continues up into the Lower Cretaceous Valhall Formation.

There has been much discussion of the origin of the organic-rich Upper Volgian-Ryazanian 'hot shales' in the North Sea. Controlling factors proposed in the literature include the development of stratified water columns in restricted basins (Tyson et al., 1979), a dryer climate during the latter part of the Late Jurassic (Wignall and Ruffell, 1990), and sediment starvation during maximum transgression (Price et al., 1993, but see also Posamentier and James, 1993).

We suggest that the 'hot unit' in the present study area may have been deposited in the early part of the transgressive systems tract, following the deposition of sandy basin floor turbidites of the lowstand systems tract. During the early transgression, sea level was still relatively low and beginning to rise slowly. Restricted basins with stratified water columns and anoxic sea bottom conditions thus persisted during the early part of the transgressive systems tract, resulting in the accumulation of organic-rich, non-bioturbated claystones. As proposed by Rawson and Riley (1982), continued sea-level rise may ultimately have resulted in turnover of the water mass with the return of oxic conditions to the deeper graben systems and the onset of deposition of the calcareous Cromer Knoll Group facies.

\section{Discussion}

A variety of methods are used to describe the sequence stratigraphic evolution of the study area. The duration and age of the ammonite zones shown in Figure 15 (from Haq et al., 1988) are presented in order to ease comparisons with the key surfaces of the Exxon chart. Although caution must be exercised when comparing with the eustatic sea level curve of Haq et al., 1988 (see Miall, 1992), correlating sequence stratigraphic key surfaces has been attempted (Figure 15).

The stratigraphic location of sequence boundaries and maximum flooding surfaces is shown in Figure 15. In some cases it has been necessary to indicate a time-interval ('age uncertainty'), ranging over several ammonite zones, for the sequence boundary or maximum flooding surface, due to poor biostratigraphic resolution. Sequence boundary $\mathrm{SB}_{4}$, and maximum flooding surface $\mathrm{MFS}_{2}$ are the most accurately dated surfaces.

\section{Tectonics versus eustasy}

Four sequences are recognized within the Mutabilis-Weatleyensis chronozones, whereas Haq et al. (1988) only recognized two sequences in the same time range (Figure 15). $\mathrm{SB}_{2}$ may be correlated with SB-142 m.y. of Haq et al. (1988), but $\mathrm{SB}_{3}$ and $\mathrm{SB}_{4}$ are not represented on the eustatic sea level curve.

The present study shows that two tectonic events occurred within the Mutabilis-Weatleyensis chronozones (Figure 15). The reservoir sandstones of the 'basal sandstone unit' within the transgressive systems tract of sequence 1 were deposited during the first tectonic phase characterized by subsidence along $\mathrm{N}-\mathrm{S}$ trending normal faults. This fault activity ceased before the deposition of the prograding sandstones in the highstand systems tract of sequence 1 and these sediments thus accumulated during a tectonically quiet period between phase 1 and 2 . The progradation of the sandstones may thus be the consequence of a reduced rate of relative sea level rise, due to a low subsidence rate. The next two sequences ( 3 and 4) were deposited during the second tectonic phase, characterized by NW-SE trending normal faulting (Figure 15).

The development of sequences may have been controlled by footwall uplift, forming new subaerial or submarine sediment source areas. Subsidence of the hanging wall would have provided greater accommodation space, resulting in thick prograding shallow marine sandstones sourced by uplifted footwall areas. This is also recognized as an important factor for the distribution of the shoreface reservoir sandstones of the Ula Formation (Stewart, 1993) and the Fulmar Formation (Wakefield et al., 1993).

$\mathrm{SB}_{5}$ may be correlated with SB-138 m.y. or SB-139 m.y. of Haq et al. (1988) (Figure 15). It is not possible to subdivide sequence 5 into systems tracts as no welldefined log patterns are recognized. Haq et al. (1988) recognized four sequence boundaries in the same interval $(139,138,136$, and 135 m.y.), including one of the most prominent sequence boundaries (136 m.y.) in the Upper Jurassic (Figure 15). The reason why we only recognize one sequence may be that the whole study area was subsiding so rapidly during tectonic phase 3 , that the eustatic sea-level falls were too small to leave a recognizable sedimentological imprint.

SB $_{6}$ may be correlated with SB-134 m.y. of Haq et al. (1988) (Figure 15). Possible correlatives of SB-131.5, SB129 and SB-128.5 m.y. (of Haq et al. (1988)) within the uppermost Jurassic have not been recognized in the present study.

In conclusion, the sequence stratigraphic boundaries of this study do not, in all cases, match those presented on the eustatic sea-level curve of Haq et al. (1988). This suggests that either the study area was influenced strongly by tectonism, and/or that the Exxon sea level curve is not eustatic. Underhill (1991) has shown that the Jurassic 


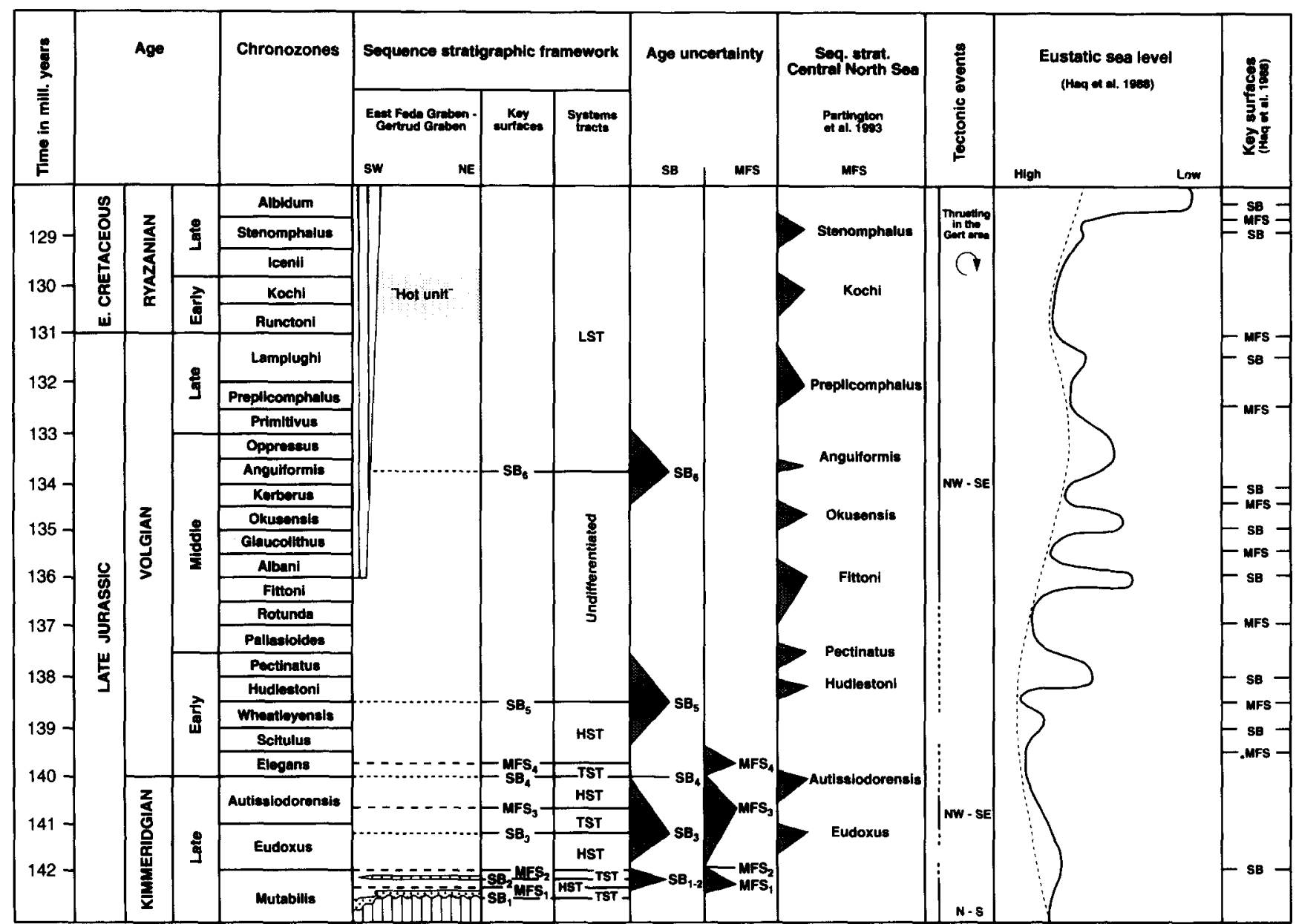

Figure 15 Time stratigraphic correlation chart of sequence stratigraphic key surfaces, systems tracts and tectonic events for the Feda Graben-Gertrud Graben area. The eustatic sea-level curve and key surfaces of Haq et al. (1988) are presented so comparison is possible. The absolute ages are from Haq et al. (1988)

of the Moray Firth, UK, was very much influenced by tectonism. A large amount of data used by Haq et al. (1988) is from the Moray Firth. Underhill (1991) thus concluded that the sea level curve of Haq et al. (1988) cannot represent a eustatic curve for Jurassic times, but must represent a relative sea level curve valid only for the local area of the Moray Firth.

\section{Regional correlations}

The sequence stratigraphic interpretations presented in this paper can be compared with the subdivision of the Late Jurassic in the central North Sea area presented by Partington et al. (1993). These workers claim that all sequences of the northern and central North Sea are controlled primarily by tectonics and sediment supply and to a lesser degree by eustatic sea level changes. Partington et al. (1993) were not able to correlate their sequences with the eustatic sea level curve of Haq et al. (1988).

According to Partington et al. (1993) the main flooding event, related to the main rift phase in the North Sea, is the 'Eudoxus' flooding occurring in the late part of the Eudoxus chronozone (Figure 15). The 'Eudoxus' flooding surface lies immediately above the shoreface sandstones of the Fulmar Formation, Central Graben, UK (Partington et al., 1993). Onshore UK, the main flooding event during the Late Jurassic also occurs during the Eudoxus chronozone (Wignall, 1991).
The main flooding event in our study area is represented by the $\mathrm{MFS}_{2}$, overlying thick shoreface sandstones of the Heno Formation. MFS 2 occurs between the Mutabilis and Eudoxus chronozones and is the most accurately dated MFS in this study (Figure 15). Consequently it seems as if the main flooding event occurs earlier in the northern part of the Danish Central Trough than in the U.K. Central Graben.

The maximum flooding surfaces defined here are difficult to correlate with those of Partington et al. (1993) (Figure 15). With the exception of the maximum flooding surface, $\mathrm{MFS}_{4}$, occurring in the Elegans chronozone, we have not recognized any maximum flooding surfaces in the Volgian-Ryazanian succession. Partington et al. (1993) identified eight such surfaces in the same time period. An explanation may be that the study area experienced large sedimentation rates during tectonic phase 3 , dominated by deposition of offshore claystones. The organic-rich claystones of the 'hot unit' are referred to the Kochi chronozone. Partington et al. (1993) recognize a maximum flooding surface within the same zone, but refer to it as a minor flooding event, compared for instance with the 'Eudoxus' flooding event. We interpret the 'hot unit' as an early transgressive deposit, following the deposition of lowstand turbidite sandstones. During the early transgression, the water column was still stratified and organic-rich sediments accumulated on the sea floor under anoxic bottom conditions. 


\section{Conclusions}

Two reservoir sandstone intervals are recognized in the Feda and Gertrud Grabens. The lower comprises aggrading to retrograding back-barrier to shoreface sandstones referred to as the 'basal sandstone unit', deposited within a transgressive systems tract. The upper consists of prograding to retrograding storm-dominated lower to middle shoreface sandstones of the Heno Formation deposited within a highstand systems tract and early transgressive systems tract.

The reservoir sandstones are of Late Kimmeridgian age and are thus considerably younger than previously thought (Figure 3) (e.g. Jensen et al., 1986; Bergan et al., 1989; Söderström et al., 1991).

Reservoir sandstones may occur in two additional areas. If the conglomerates of the Heno Formation on the Gertrud Plateau were deposited as the result of relative sea level fall, it is possible that shoreface sandstones with good reservoir quality may be found within the south-eastern part of the Feda Graben. The presence of thin-bedded turbidite sandstones forming the lowstand systems tract of sequence 6 suggests that thicker, amalgamated turbidite sandstones may be found nearer to the sediment source area, i.e. proximal to the Mandal High.

\section{Acknowledgements}

The work of Peter Johannessen forms part of a PhD thesis at the University of Copenhagen, supported financially by the Ministry of Energy and the Geological Survey of Denmark and supervised by F. Surlyk, University of Copenhagen. Maersk Olie og Gas A/S financed the biostratigraphical part of the project. Jon Ineson is thanked for constructive criticism which improved the paper and for correcting the English. We wish to thank our colleagues at the Stratigraphy and Geophysics Divisions of the Geological Survey of Denmark for fruitful and stimulating discussions. Petrophysical logs were processed by Inger Merete Jensen. Eva Melskens and Helle Zetterwall produced the drawings and Benny Schark did the repro work. Palynological slides were produced by Ingerlise Nørgaard, Yvonne Desezar and Anne Marie Rasmussen.

\section{References}

Bergan, M., Torudbakken, B. and Wandås, B. (1989) Lithostratigraphic correlation of Upper Jurassic sandstones within the Norwegian Central Graben: Sedimentological and tectonic implications. In: Correlation in Hydrocarbon exploration (Ed. J. D. Collinson), Norwegian Petroleum Society. Graham Trotman, 243-251

Damtoft, K., Nielsen, L. H., Johannessen, P. N., Thomsen, E. and Andersen, P. R. (1992) Hydrocarbon plays of the Danish Central Trough. In: Generation, Accumulation and Production of Europe's Hydrocarbons II (Ed. A. M. Spencer), SpringerVerlag, 35-58

Doré, A. G. and Gage, M. S. (1987) Crustal alignments and sedimentary domains in the evolution of the North Sea, Northeast Atlantic margin and Barents Shelf. In: Petroleum Geology of North West Europe (Eds J. Brooks and K. Glennie), Graham and Trotman, London, 1131-1148

Gage, M. S. and Doré, A. G. (1986) A regional geological perspective of the Norwegian offshore exploration provinces. In: Norwegian Petroleum Society, Habitat of Hydrocarbons on the Norwegian Continental Shelf (Eds A. M. Spencer et al.) Graham and Trotman, London, 21-38

Hallam, A. (1988) A re-evaluation of Jurassic eustasy in the light of new data and the revised Exxon curve. In: Sea-level Changes: an integrated Approach (Eds C. K. Wilgus, B. S. Hastings, C. G. St. C. Kendall, H. Posamentier, C. A. Ross and J. van Wagoner), Society of Economic Paleontologists and Mineralogists Special Publication 42, 261-273

Haq, B. U., Hardenbol, J. and Vail, P. R. (1988) Mesozoic and Cenozoic chronostratigraphy and eustatic cycles. In: Sea-level Changes: an Integrated Approach (Eds C. K. Wilgus, B. S. Hastings, C. G. St. C. Kendall, H. Posamentier, C. A. Ross and J. van Wagoner), Society of Economic Paleontologists and Mineralogists Special Publication 42, 71-108

Heilmann-Clausen, C. (1987) Lower Cretaceous dinoflagellate biostratigraphy in the Danish Central Trough. Danmarks Geologiske Undersogelse Ser. A 17, $89 \mathrm{pp}$

Howell, J. A., Flint, S. S. and Hunt, C. (1996) Sedimentological aspects of the Humber Group (Upper Jurassic) of the South Central Graben UK North Sea Sedimentology 43, 89-114

Jensen, T. F., Holm, L., Frandsen, N. and Michelsen, O. (1986) Jurassic-Lower Cretaceous lithostratigraphic nomenclature for the Danish Central Trough. Danmarks Geologiske Undersogelse Serie A 12, 65 pp

Johannessen, P. N. and Andsbjerg, J. (1993) Middle to Late Jurassic basin evolution and sandstone reservoir distribution in the Danish Central Trough. In: Petroleum Geology of Northwest Europe: Proceedings of the 4th conference (Ed. J. R. Parker), 271-283

Johnson, H. D., Mackay, T. A. and Stewart, D. J. (1986) The Fulmar Oil-field (Central North Sea): geological aspects of its discovery, appraisal and development Mar. Petrol. Geol. 3, 99-125

Lowe, D. R. (1979) Sediment gravity flows: their classification and some problems of application to natural flows and deposits. In: Geology of Continental Slopes (Eds L. J. Doyle and O.H. Pilkey) Spec. Publs Soc. econ. Paleont. Miner. Tulsa 27, 75-82

Miall, A. D. (1992) Exxon global cycle chart: An event for every occasion? Geology 20, 787-790

Michelsen, O. and Wong Th.E. (1991) Discussion of the Jurassic lithostratigraphy in the Danish, Dutch, and Norwegian Central Graben areas. In: The Jurassic in the Southern Central Trough (Eds O. Michelsen and N. Frandsen) Danmarks Geologiske Undersogelse Serie B 16, 20-28

Michelsen, O., Frandsen, N., Holm, L., Jensen, T. F., Møller, J. J. and Vejbæk, V. (1987) Jurassic-Lower Cretaceous of the Danish Central Trough; depositional environments, tectonism, and reservoirs Danmarks Geologiske Undersogelse Serie A 16,45

Noe-Nygaard, N., Surlyk, F. and Piasecki, S. (1987) Bivalve mass mortality caused by toxic dinoflagellate blooms in a Berriasian-Valanginian lagoon Bornholm, Denmark Palaios 2, 263273

Partington, M. A., Copestake, P., Mitchener, B. C. and Underhill, J. R. (1993) Biostratigraphic calibration of genetic stratigraphic sequences in the Jurassic-lowermost Cretaceous (Hettangian to Ryazanian) of the North Sea and adjacent areas. In: Petroleum Geology of the Northwest Europe: Proceedings of the 4th Conference (Ed. J. R. Parker), Geol. Soc., London, 371386

Posamentier, H. W. and James, D. P. (1993) An overview of sequence stratigraphic concepts: uses and abuses. In: Sequence stratigraphy and facies associations (Eds $\mathrm{H}$. W. Posamentier, C. P. Summerhayes, B. U. Haq and G. P. Allen) Spec. Publs Int. Ass. Sediment. 18, 3-18

Poulsen, N. E. (1991) Upper Jurassic dinocyst stratigraphy in the Danish Central Trough. In: The Jurassic in the Southern Central Trough (Eds O. Michelson and N. Frandsen) Danmarks Geologiske Undersogelse Serie B 16, 7-15

Price, J., Dyer, R., Goodall, I., McKie, T., Watson, P. and Williams, G. (1993) Effective stratigraphical subdivision of the Humber Group and the Late Jurassic evolution of the UK Central Graben. In: Petroleum Geology of Northwest Europe: Proceedings of the 4th conference (Ed. J. R. Parker), 443-458

Rasmussen, E. S. (1995) Structural evolution of the Gert-MjøIner Field Mar. Petrol. Geol. 12, 377-385

Rawson, P. F. and Riley, L. A. (1982) Latest Jurassic-Early Cretaceous events and the Late Cimmerian Unconformity in the North Sea area Bull. Am. Ass. Petrol. Geol. 66, 2628-2648

Roberts, A. M., Price, J. D. and Olsen, T. S. (1990) Late Jurassic half-graben control on the siting and structure of hydrocarbon 


\section{Upper Jurassic reservoir sandstones: P. N. Johannessen et al.}

accumulations: UK/Norwegian Central Graben. In: Tectonic events responsible for Britain's oil and gas reserves (Eds $\mathbf{R}$. F. P. Hardmand and J. Brooks) Spec. Publ. Geol. Soc. 55, 229257

Smelror, M. and Leereveld, H. (1989) Dinoflagellate and acritarch assemblages from the Late Bathonian to Early Oxfordian of Montagne Crussol, Rhone Valley, Southern France Palynology 13, 121-141

Stewart, I. J. (1993) Structural controls on the Late Jurassic age shelf system, Ula Trend, Norwegian North Sea. In: Petroleum Geology of Northwest Europe: Proceedings of the 4th conference (Ed. J. R. Parker), 469-483

Söderström, B., Forsberg, A., Holtar, E. and Rasmussen, B. A. (1991) The Mjølner Field, a deep Upper Jurassic oil field in the Central North Sea First Break 9, 156-171

Sundsbe, G. O. and Megson, J. B. (1993) Structural styles in the Danish Central Graben. In: Petroleum Geology of Nothwest Europe: Proceedings of the 4th conference (Ed. J. R. Parker), 1255-1268

Taylor, A. M. and Gawthorpe, R. L. (1993) Application of sequence stratigraphy and trace fossil analysis to reservoir description: examples from the Jurassic of the North Sea. In Petroleum Geology of Nothwest Europe: Proceedings of the 4th conference (Ed. J. R. Parker), 317-335

Tyson, R. V., Wilson, R. C. L. and Downie, C. (1979) A stratified water column environmental model for the type Kimmeridge Clay Nature 277, 377-380
Underhill, J. R. (1991) Controls on Late Jurassic seismic sequences, Inner Moray Firth, UK North Sea: a critical test of key segment of Exxon's original global cycle chart Basin Research 3, 79-98

Vollset, J. and Doré, A. G. (Eds) (1984) a revised Triassic and Jurassic lithostratigraphic nomenclature for the Norwegian North Sea. Norwegian Petroleum Directorate, Bulletin 3, 53 $\mathrm{pp}$

Wakefield, L. L., Droste, H., Giles, M. R. and Janssen, R. (1993) Late Jurassic plays along the western margin of the Central Graben. In: Petroleum Geology of Northwest Europe: Proceedings of the 4th conference (Ed. J. R. Parker), 459-468

Wignall, P. B. (1991) Test of the concepts of sequence stratigraphy in the Kimmeridgian (Late Jurassic) of England and northern France Mar. Petrol. Geol. 8, 430-441

Wignall, P. B. and Ruffell, A. H. (1990) The influence of sudden climatic change on marine deposition in the Kimmeridgian of North West Europe J. Geol. Soc. London 147, 365-372

Wollam, R. and Riding, J. B. (1983) Dinoflagellate cyst zonation of the English Jurassic. Rep. Inst. Geol. Sci. 83, 41 pp

Ziegler, P. A. (1982) Geological Atlas of Western and Central Europe. Elsevier, Amsterdam, $130 \mathrm{pp}$

Ziegler, P. A. (1988) Evolution of the Arctic-North Atlantic and the Western Tethys. Am. Ass. Petrol. Geol. Mem. 43, 197pp

Ziegler, P. A. (1990) Geological Atlas of Western and Central Europe. Shell Internationale Petroleum Maatschappij, 239pp 